\section{Into trees but not out of the wood}

In 1960, forestry and the wood, pulp and paper industry accounted for 69 per cent of Finland's exports. The proportion has since dropped to 36 per cent, largely because of a policy of diversification in the nation's technology, but with 65 per cent of the country coverered by forest, it is not surprising that new technologies, like genetic engineering, have a bias towards traditional applications.

Most of the trees in Finland's forests are pine and spruce, but it is the long-fibre properties of South American eucalyptus, which cannot grow so far north, that are most in demand for contemporary papermaking. Birch is the only native species

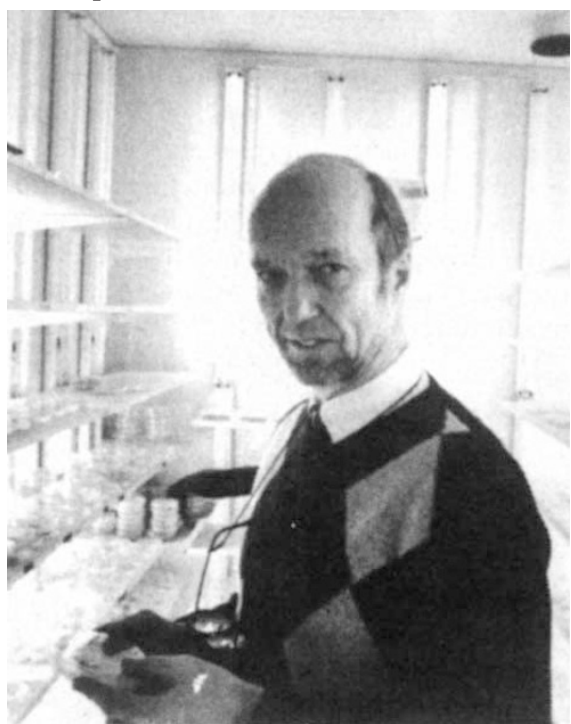

Dr Veli Kauppinen with birch embryos pro duced from 'artificial seeds' at the VTT Biotechnical Laboratory.

that can compete with eucalyptus, but it has been difficult to cultivate on a large scale. Using biotechnology techniques, a research group at the Biotechnical Laboratory of the Technical Research Centre of Finland (VTT) thinks it has found a solution.

"The problem", says Veli Kauppinen, who is directing the research, "is that rodents eat up to 80 per cent of our birch seedlings in winter. It is the presence of secondary metabolites, which do not taste nice, that allows the other 20 per cent to survive".

The rodent-resistant variety cannot be multiplied by seed, since the trees lose their resistance, while vegetative techniques are too laborious for commercial applications. So Kauppinen has developed cloning techniques to make artificial seeds, which are then used to produce embryos in suspension. These can then be cultivated.

In the same laboratory, Jonathen Knowles is working in collaboration with the Finnish Pulp and Paper Research
Institute, a private corporation owned by the Finnish paper industries, to look at ways of producing new enzymes to replace chlorine chemicals in wood bleaching part of a national drive to reduce pollution of Finland's lakes.

Knowles, an Englishman, was one of a group of scientists who introduced recombinant DNA techniques to Finland at the beginning of the $1980 \mathrm{~s}$, as part of a 3-year research project funded by SITRA, the Finnish National Fund for Research and Development. Housed at the Meilahti Institutes and the National Public Health Institute in Helsinki, the project brought together virologists, bacteriologists, and protein and nucleic acid chemists, and gave Finnish biotechnology the start it needed.

Following on from this project, a recombinant DNA laboratory was set up
Energy
Over the past decade Finland has become one of the top four nuclear nations, currently producing 34 per cent of its electricity and 16 per cent of all energy by nuclear power. Energy-intensive process industries, the cold climate and long, dark sumption per head one of the highest in the world, behind only the United States and Sweden. Yet it has no high-grade fossil fuel resources and only limited potential for hydropower. Although there are over 55,000 lakes in the country, they contain relatively little water and the terrain is flat.

As a result, energy, particularly in the form of oil, accounts for 16 per cent of the value of all imports with 76 per cent coming from the Soviet Union. Finland has tried to diversify its energy sources, but its options are limited. As in Sweden, peat is plentiful, but seasonal restrictions on harvesting and high transporation costs make it an impractical fuel on a large coal-burning electricity generators make them increasingly unacceptable A bilateral trade agreement with the Soviet Union, signed just after the Second World War, means that Finland cannot increase energy imports from its neighbour without increasing its exports, which is impossible so long as oil prices remain low.

Nuclear power therefore became a natural choice for Finland, especially after the oil crisis of the $1970 \mathrm{~s}$. There are currently four reactors in operation, producing a total of 2,300 $\mathrm{MW}$. The state-owned Imatra Power Company operates two 440MW pressurized light water reactors, are winters help make Finland's energy conscale. Pollution of lakes and forests by in 1982 by the University of Helsinki, with funds from the Academy of Finland, the Ministry of Education, SITRA and Finnish industry. Many of the original researchers have now left to form their own research groups and, this year, Genesit $\mathrm{Oy}$, an industry-sponsored group working within the university recombinant DNA laboratory on the development of host and vector systems in Bacillus, will become an autonomous commercial enterprise.

Nevertheless, a report published by the Academy of Finland this year says that an extra financial input of FIM 37 million per year, for the next five years, will be needed in order to bring Finnish biotechnology and molecular biology research up to the standard required to compete internationally. The Academy has targetted research training and new equipment as specific goals and hopes that different sectors of government, such as the Ministry for Agriculture and Forestry, will provide special funding for research groups. $\square$

\title{
Hobson's choice on nuclear power
}

situated at Loviisa, about $100 \mathrm{~km}$ east of Helsinki and were built with components supplied by a Soviet export organization, $\mathrm{V} / \mathrm{O}$ Atomenergoexport, better known as 'Eastinghouse'

The other two reactors are operated by the Industrial Power Company, a private consortium with the state as 50 per cent shareholder. These 660-MW Swedishdesigned boiling water type reactors are situated on the south-west coast, at Olkiluoto.

Plans to build a fifth reactor were suspended by the present coalition government following public nervousness after the Chernobyl disaster, even though Finland was less affected than was at first thought. Finland still needs to find an alternative source of extra power to cope with a forecast growth in demand. During last winter's severe weather, the country found itself with only $0.4 \mathrm{MW}$ spare capacity at peak times.

Unlike Sweden which is committed to life without nuclear power by the year 2010 (see page 342), Finland does not intend to shut existing reactors. When the encumbent government's mandate expires in 1991, plans for the fifth reactor may even be dusted off. Whatever happens, a major problem that is more than likely to face Finland's nuclear industry in the next decade will be the recruitment of sufficient nuclear engineers. Once considered a glamorous occupation, the nuclear industry is now finding it hard to fill vacancies, while nuclear engineering departments of Finland's technical universities are attracting fewer students. 